\title{
Dominant forest tree species potentially vulnerable to climate change over large portions of their range even at high latitudes
}

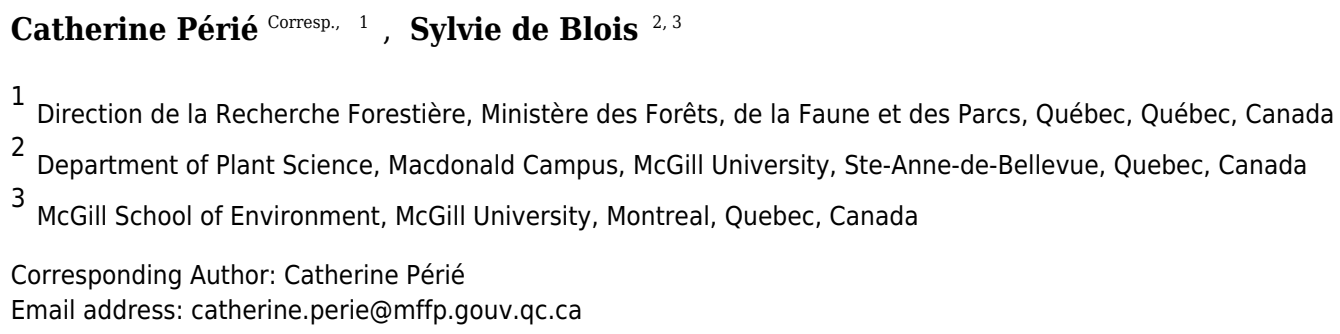

Projecting suitable conditions for a species as a function of future climate provides a reasonable, although admittedly imperfect, spatially explicit estimate of species vulnerability associated with climate change. Projections emphasizing range shifts at continental scale, however, can mask contrasting patterns at local or regional scale where management and policy decisions are made. Moreover, models usually show potential for areas to become climatically unsuitable, remain suitable, or become suitable for a particular species with climate change, but each of these outcomes raises markedly different ecological and management issues. Managing forest decline at sites where climatic stress is projected to increase is likely to be the most immediate challenge resulting from climate change. Here we assess habitat suitability with climate change for five dominant tree species of eastern North American forests, focusing on areas of greatest vulnerability (loss of suitability in the baseline range) in Quebec (Canada) rather than opportunities (increase in suitability). Results show that these species are at risk of maladaptation over a remarkably large proportion of their baseline range. Depending on species, 5 to $21 \%$ of currently climatically suitable habitats are projected to be at risk of becoming unsuitable. This suggests that species that have traditionally defined whole regional vegetation assemblages could become less adapted to these regions, with significant impact on ecosystems and forest economy. In spite of their well-recognised limitations and the uncertainty that remains, regionally-explicit risk assessment approaches remain one of the best options to convey that message and the need for climate policies and forest management adaptation strategies. 
1 Dominant forest tree species potentially vulnerable to climate change over large portions of

\section{2 their range even at high latitudes}

3

$4 \quad$ Catherine Périé ${ }^{1}$ and Sylvie de Blois ${ }^{2,3}$

5

61 Direction de la recherche forestière, ministère des Forêts, de la Faune et des Parcs, 2700

7 rue Einstein, Québec, Québec, G1P 3W8, Canada.

82 Department of Plant Science, Macdonald Campus of McGill University, 21111 Lakeshore,

9 Ste-Anne-de-Bellevue, Québec, H9X 3V9, Canada.

103 McGill School of Environment, Macdonald Campus of McGill University, 21111

11 Lakeshore, Ste-Anne-de-Bellevue, Québec, H9X 3V9, Canada.

12

13 Corresponding author:

14 Catherine Périé

15 Direction de la recherche forestière, ministère des Forêts, de la Faune et des Parcs, 2700 rue

16 Einstein, Québec, Québec, G1P 3W8, Canada

17 Email address: catherine.perie@mffp.gouv.qc.ca 


\section{ABSTRACT}

21 Projecting suitable conditions for a species as a function of future climate provides a reasonable,

22 although admittedly imperfect, spatially explicit estimate of species vulnerability associated with

23 climate change. Projections emphasizing range shifts at continental scale, however, can mask

24 contrasting patterns at local or regional scale where management and policy decisions are made.

25 Moreover, models usually show potential for areas to become climatically unsuitable, remain

26 suitable, or become suitable for a particular species with climate change, but each of these

27 outcomes raises markedly different ecological and management issues. Managing forest decline

28 at sites where climatic stress is projected to increase is likely to be the most immediate challenge

29 resulting from climate change. Here we assess habitat suitability with climate change for five

30 dominant tree species of eastern North American forests, focusing on areas of greatest

31 vulnerability (loss of suitability in the baseline range) in Quebec (Canada) rather than

32 opportunities (increase in suitability). Results show that these species are at risk of maladaptation

33 over a remarkably large proportion of their baseline range. Depending on species, 5 to $21 \%$ of

34 currently climatically suitable habitats are projected to be at risk of becoming unsuitable. This

35 suggests that species that have traditionally defined whole regional vegetation assemblages could

36 become less adapted to these regions, with significant impact on ecosystems and forest economy.

37 In spite of their well-recognised limitations and the uncertainty that remains, regionally-explicit

38 risk assessment approaches remain one of the best options to convey that message and the need

39 for climate policies and forest management adaptation strategies. 


\section{Introduction}

41 During the last century, forest conservation policies and management practices worldwide have

42 been developed assuming a relatively stable climate regime. Indeed, apart from occasional extreme 43 events, climate was largely considered as a stable dimension, over decades or centuries, of a 44 species' niche or habitat. Although tree species distribution ranges have expanded or shrunk in 45 response to climate, detectable shifts largely occurred at time scales comparable to those of climate 46 change in the Quaternary, that is, within centuries or millennia for long-lived trees (Davis et al. 47 2005). In the coming decades, however, boreal forests are predicted to face multiple stresses under 48 a rapidly warming climate, including increased frequency of forest fires and insect and disease 49 outbreaks (Gauthier et al. 2015). Global mean temperatures are projected to increase at rates 50 unprecedented in human history (Diffenbaugh \& Field 2013). By the mid-21 ${ }^{\text {st }}$ century, many areas 51 of the globe will be under a new climate regime, in which the coolest warm-season months of the $5221^{\text {st }}$ century are predicted to be hotter than the hottest warm-season months of the late $20^{\text {th }}$ century 53 (Diffenbaugh \& Scherer 2011), while considerable regional and interannual variability is expected.

54 Impacts could be profound on forest species distributions, community structure, and ecosystem 55 functions, as well as on all economic activities and services that depend on forests (Hanewinkel et al. 2012; Price et al. 2013).

Projecting suitable conditions for a species as a function of future climate provides a reasonable, although admittedly imperfect, spatially explicit estimate of tree vulnerability

59 associated with climate change in this century (Araújo \& Peterson 2012; Elith \& Leathwick 2009;

60 Franklin 2013). Species distribution or habitat suitability models have projected dramatic range

61 shifts at continental scales for hundreds or thousands of species at a time, greatly helping raise 
62 concerns about biodiversity and climate change (Iverson et al. 2008; Ray et al. 2010; Thuiller et

63 al. 2008; Xiao-Ying et al. 2013). Projections will usually show potential for areas to become

64 climatically unsuitable, remain suitable, or become suitable for a particular species with climate

65 change compared to baseline climatic conditions. Each of these outcomes, however, raises

66 markedly different ecological and management issues. For instance, the potential for habitat gain

67 under warmer climatic conditions exists but natural tree range expansion or tree migration is

68 unlikely to proceed at rates sufficient to keep up with climate change in this century (Boisvert-

69 Marsh et al. 2014; Renwick \& Rocca 2015; Savage \& Vellend 2015), whereas the introduction of

70 species outside their natural range is questioned (Aubin et al. 2011). On the other hand, if climatic

71 conditions are projected to become unsuitable for a species, many areas are likely to retain

72 maladapted trees given trees' long lifespan; this could affect forest productivity and species

73 turnover at a site. Species decline will have immediate consequences on local community

74 processes, forest management practices, and related economic activities. Unless forests change

75 mostly through catastrophic events, it is likely that managing forest decline at sites where climatic

76 stress is becoming increasingly important will be the most immediate challenge of climate change.

77 Finally, projections at continental scale that emphasize major range shifts may mask contrasting

78 patterns at local or regional scale, while forest managers, conservationists, or policymakers need

79 to understand site-specific impacts to inform adaptation strategies, forest policies, or monitoring

80 efforts. Monitoring sites at risk, in particular, is increasingly important to determine whether recent

81 climate change is already affecting population dynamics (Girardin et al. 2014; Worrall et al. 2013)

82 or species distributions (Boisvert-Marsh et al. 2014; Woodall et al. 2009), or whether species can

83 indeed persist under novel climatic conditions. 

survey programs in Quebec (Canada) and the eastern United-States to assess potential decline in habitat suitability associated with climate change for five dominant tree species of deciduous and coniferous forests. Given the ecological and economic importance of these species, a change in their distribution and dynamics could make entire ecosystems, ecoregions, and economies vulnerable. Consequently, we focus on areas where climate is predicted to become unsuitable or less suitable for these species as opposed to habitat gain or range shift to emphasize vulnerabilities rather than opportunities. These species are, in order of decreasing merchantable volume in Quebec forests: Picea mariana (Mill.) Britton, Sterns \& Poggenb. (black spruce), Abies balsamea (L.) Mill. (balsam fir), Betula papyrifera Marshall (white birch, synonym of paper birch), Acer saccharum Marsh. (sugar maple) and Betula alleghaniensis Britton (yellow birch). We base our assessment on a rigorous modelling approach using data spanning two jurisdictions (United States and Canada), but focus our interpretation at the scale of ecologically and economically significant

97 bioclimatic domains which are defined by the target species in Quebec forests. We assume that 1) even though other factors can limit tree distribution (Beauregard \& de Blois 2014; Lafleur et al. 2010), climate remains a significant determinant of a species' fundamental niche (Araújo \& Peterson 2012), given its major role in determining species presence and genetic variation across

101 landscapes (Jansen et al. 2007; Woodward \& Williams 1987); 2) climate models coupled with 102 greenhouse gas emission scenarios provide a reasonable estimate of climatic conditions in this 103 century; 3) assessing potential decline in habitat suitability for a species provides an estimate of

104 the risk of climate-related stress for that species; and 4) stakeholders need spatially explicit 105 projections at a scale relevant to decision making, since trees regenerating today will cope with 106 climate conditions that may drastically change during their lifespan. This is especially the case in 
107 boreal forests where most tree species grow slowly (Ministère des Ressources Naturelles 2013).

108 We discuss the significance of these projections for species conservation and management

109 scenarios, recognising the effect of uncertainty on adaptation strategies.

\section{Materials \& Methods}

\section{Study area}

112 We focused our study on forests of Quebec (Canada), which account for $20 \%$ of the total

113 Canadian forests and 2\% of the world's forests. Dense forests cover an area of 761,100 $\mathrm{km}^{2}$,

114 (equivalent in size to the territories of Norway and Sweden combined -

115 https://www.mern.gouv.qc.ca/english/international/forests.jsp), of which 70\% is considered

116 productive (commercial forest managed under the Sustainable Forest Development Act). Quebec

117 forests are largely under public management (91.6\% of forest land) with the responsible ministry

118 allocating harvesting rights. The productive forest territory $\left(45^{\circ} \mathrm{N}-53^{\circ} \mathrm{N}\right)$ mainly comprises the

119 northern temperate and boreal vegetation zones (Fig. 1), which reflect Quebec's major climatic

120 gradient. The zones are further divided, on the basis of edaphic and climatic conditions, into

121 characteristic plant communities of ecological and economic importance or bioclimatic domains.

122 The temperate zone includes, from south to north: the sugar maple-bitternut hickory domain

$123\left(14,500 \mathrm{~km}^{2}\right)$, the sugar maple-basswood domain $\left(31,000 \mathrm{~km}^{2}\right)$, the sugar maple-yellow birch

124 domain $\left(65,600 \mathrm{~km}^{2}\right)$ - all three being grouped in this study as the sugar maple domains — and

125 the balsam fir-yellow birch domain $\left(98,600 \mathrm{~km}^{2}\right)$. The boreal zone includes the balsam fir-white

126 birch domain $\left(139,000 \mathrm{~km}^{2}\right)$, the very large spruce-moss domain $\left(412,400 \mathrm{~km}^{2}\right)$, and the spruce-

127 lichen domain $\left(299,900 \mathrm{~km}^{2}\right)$ which extends to $55^{\circ} \mathrm{N}$. 
We constructed habitat suitability models for each species using a modelling area largely

129

130

131

132

133

134

135

136

137

138

139

140

141

142

143

144

145

146

147

148

149

150

exceeding that of the province taking into account the expected shift north of climate envelope according to various climate simulations (Logan et al. 2011) as well as available data on current species distribution and climate and edaphic conditions. The modelling area $\left(\sim 2,500,000 \mathrm{~km}^{2}\right)$ ranges from $30^{\circ} \mathrm{N}$ to $53^{\circ} \mathrm{N}$ in latitude and from $93^{\circ} \mathrm{W}$ to $60^{\circ} \mathrm{W}$ in longitude (Fig. 1). Annual mean temperature increases gradually from $-5^{\circ} \mathrm{C}$ in the north to $+20{ }^{\circ} \mathrm{C}$ in the south, whereas annual total precipitation ranges from 670 to $2,000 \mathrm{~mm}$, with less of a spatial gradient. Elevation ranges from sea level to $1,250 \mathrm{~m}$.

We based the geographic grid we used for modelling on that of the Climate Change Atlas for 134 Forest Tree Species of the Eastern United States (Iverson et al. 2008; Landscape Change Research Group 2014). This grid was extended into Quebec to allow the merging of data sets from both jurisdictions. The mapped area is composed of 6,418 cells $\left(20 \times 20-\mathrm{km}\right.$ or $400-\mathrm{km}^{2}$ each, Fig. 1), each considered as a sampling unit and containing information on tree species occurrence, climate, elevation and edaphic characteristics.

Ideally, the modelling area should include the vast majority of the range of climatic conditions experienced by a species (Barbet-Massin et al. 2010), including the range of projected climatic conditions according to scenarios of climate change in the study area. Covering the full distribution range of a species is not always possible and so, in preliminary analyses, we verified gaps in climate coverage for each species by comparing the modelling area with Little's range, which is assumed to cover an entire species range in North America (Little 1971). There were minimal or no gap in temperature coverage for sugar maple (Fig. S1A), yellow birch (Fig. S2A), and balsam fir (Fig. S3A; coverage of $100 \%, 100 \%$, and $97 \%$ of the temperature range respectively). Temperature coverage was $70 \%$ for white birch (Fig. S4A) and $61 \%$ for black 
151 spruce (Fig. S5A), but the gaps were for colder temperatures that are not characteristic of the

152 projected climate trends in the study area $\left(+1.9^{\circ} \mathrm{C}\right.$ to $+8{ }^{\circ} \mathrm{C}$; Ouranos 2015$)$. Precipitation

153 coverage was $98 \%$ for both sugar maple (Fig. S1B) and yellow birch (Fig.S2B), and 70\% for

154 balsam fir (Fig. S3B). The gaps for white birch (35\%; Fig. S4B) and black spruce (31\%; Fig.

$155 \mathrm{~S} 5 \mathrm{~B})$ were towards drier annual climates that are also not characteristic of the projected climate

156 trends in the study area (precipitations $+3 \%$ to $+26 \%$; Ouranos 2015 ).

\section{Occurrence data and target species}

158 For the eastern United States, our main source of information was the Climate Change Atlas

159 database (Landscape Change Research Group 2014). For the Canadian part of the modelling

160 area, we obtained data on tree species occurrence from more than 95,000 forest plots sampled

161 across the province and inventoried from 1985 to 1998 by the ministère des Forêts, de la Faune

162 et des Parcs (Quebec's Ministery of Forests, Wildlife and Parks). The presence (or absence) of

163 each forest tree species was recorded in each of the 6,418 cells of the modelling area.

164 The five target species (sugar maple, yellow birch, white birch, balsam fir, and black

165 spruce) are common and widespread in the study area, and define the major bioclimatic domains

166 described previously. The ecological and economic importance of these species cannot be

167 overemphasized for the province: together, they represent $72 \%$ of the total volume of

168 merchantable trees (Fig. S6), and many local economies are tightly linked to their fate. Their

169 average longevity ranges from 150 years (balsam fir) to more than 300 years (sugar maple and

170 yellow birch) (Ministère des Ressources Naturelles 2013). Projections to the end of this century

171 are thus well within their lifespan. 


\section{Environmental data}

173 We used 14 predictor variables for modelling (Table 1), including 3 climate, 1 elevation, 7 soil-

174 class, and 3 soil property variables. The three climate variables were selected among a set of

175 climate variables through cluster analysis (see below). Collinearity diagnostics measuring the

176 relationship between the selected climate variables and other environmental variables were done

177 using several methods (pairwise scatterplots, correlation coefficients, condition index, variance

178 inflation factor). Collinearity was not found to be an issue at the scale of this study and for these

179 sets of variables.

180 Climatic data

181 Normalized (1961-1990) monthly surfaces of total precipitation and average, maximum,

182 and minimum temperatures were downloaded from the USDA Forest Service Rocky Mountain

183 station website (http://forest.moscowfsl.wsu.edu), as were other derived climatic variables (see

184 Rehfeldt et al. 2006 for more details). Data were obtained at a spatial resolution of 0.0083 decimal

185 degrees $(\approx 1 \mathrm{~km})$ and averaged for each $20 \times 20-\mathrm{km}$ grid cell of the modelling area. Climate

186 variables tend to be highly correlated, so we used the VARCLUS procedure in SAS 9.2 (SAS

187 Institute Inc. 2008) to find groups of variables that were as correlated as possible among

188 themselves and as uncorrelated as possible with variables in other clusters. This analysis led to

189 three clusters; in each cluster, we then selected one climate variable influencing plant survival and

190 growth. They were mean annual temperature (TEM), mean annual precipitation (PRE) and useful

191 precipitation (i.e., the ratio of the sum of June, July, August and September monthly precipitation

192 to total annual precipitation; PRATIO).

193 Ouranos (http://www.ouranos.ca/en/), a consortium on regional climatology and

194 adaptation to climate change, provided different climate simulations using output from 
19512 general and one regional coupled atmosphere-ocean general circulation models. Each of these

196 was coupled with 1, 2 or 3 projected greenhouse gas emissions scenarios (scenarios B1, A1B

197 and/or A2, based on the Special Report on Emissions Scenarios, or SRES;

198 http://www.ipcc.ch/ipccreports/sres/emission/index.php?idp=0). This generated a total of

19970 climate simulations, which are a subset of the 86 climate simulations (Logan et al. 2011)

200 made available from phase 3 of the Coupled Model Intercomparison Project (Meehl et al. 2007).

201 For each climate simulation, future (2071-2100) TEM, PRE and PRATIO values were

202 obtained using the "change field" method (IPCC 1995). Monthly mean differences between the

203 baseline period model run (1961-1990) and the future climate model run (2071-2100) were

204 calculated and then combined with baseline values of the observed monthly climate data set.

205 However, due to the relatively coarse spatial resolution of the climate simulations (45 $\mathrm{km}$ per cell

206 side for the regional coupled atmosphere-ocean model, and $\sim 250-\mathrm{km}$ per cell side for the general

207 coupled atmosphere-ocean circulation models), monthly delta values for the centroids of each

$20820 \mathrm{~km} \times 20-\mathrm{km}$ grid cell $(6,418$ in all $)$ were interpolated using a linear triangle-based

209 interpolation method (de Berg et al. 2008) between climate model grid cell centroids. Climate

210 simulations for each month were then created by applying interpolated delta values to each

211 observed grid cell value.

212 To maintain a range of variability in climate projections while reducing computation

213 time, we selected 7 of the 70 available climate simulations as drivers (Table S1), using an

214 objective approach that employs a k-means clustering approach to obtain a good coverage of

215 overall future uncertainty (Casajus et al. 2016). We considered all selected scenarios as

216 equiprobable in this analysis. 
218 Pathways (RCPs), which became available with the IPCC fifth assessment report and after this

219 study was initiated. The RCPs span a larger range of stabilization, mitigation and non-mitigation

220 pathways than the range covered by the SRES we used (Table S2). As a result, the RCPs now

221 estimate a larger range of temperature increase than the SRES (Rogelj et al. 2012). Moreover,

222 climate models have also been developed since phase 3 of the Coupled Model Intercomparison

223 Project - CMIP3, particularly by including the representation of biogeochemcal cycles (Flato et al.

224 2013). Some models do perform better than others for certain climate variables, but no individual

225 model is clearly the best overall. The comparison of median model capability in reproducing

226 historical climate shows relatively modest improvement between CMIP3 and the current CMIP5

227 generation (Flato et al. 2013). Each generation exhibits a range in performance, with CMIP5

228 showing fewer 'bad models' than CMIP3, but the species distribution modelling uses a consensus

229 approach similar to looking at an ensemble mean of General Circulation Models. As well, for

230 climate projections, we used the delta method (see above) where only relative changes from the

231 GCMs are calculated and then applied to observed data. In this case, a similar range in changes of

232 temperature and precipitation between CMIP5 and CMIP3 is what matters most in terms of species

233 distribution model results. A detailed comparison of CMIP3 and CMIP5 is beyond the scope of

234 this paper, but interested readers can consult Flato et al. (2013), particularly their Figure 9.44 and

235 Figure 1 of FAQ 9.1.

236 Topographic and soil data

237 Elevation data were provided by the Climate Change Tree Atlas database for the eastern United

238 States portion of the modelling area (Landscape Change Research Group 2014), whereas for

239 Quebec it was obtained from the Canadian Surface Model Mosaic 
240 (http://geogratis.gc.ca/api/en/nrcan-rncan/ess-sst/3A537B2D-7058-FCED-8D0B-

241 76452EC9D01F.html) at a resolution of ca. $20 \mathrm{~m}$ and averaged to match our grid. For the

242 eastern United States part of the modelling area, we obtained soil characteristics data (surface

243 deposit and drainage class; Table 1) from the NRCS Soil Survey data (version 2.1, scale

244 1:24,000; Soil Survey Staff, Natural Resources Conservation Service, United States Department

245 of Agriculture. Web Soil Survey. Available online at http://websoilsurvey.nrcs.usda.gov/). For

246 the Quebec part, we used soil data from the $3^{\text {rd }}$ decennial permanent and temporary surveys

247 (1:20 000 scale) of the ministère des Forêts, de la Faune et des Parcs, Quebec (available on

248 request at http://www.mffp.gouv.qc.ca/forets/inventaire/donnees-inventaire.jsp). For each grid

249 cell, we computed the percentage of the $20 \times 20-\mathrm{km}$ cell occupied by each level of each edaphic

250 variable.

251 Modelling current and future habitat suitability

252 Species distribution modelling

253 We computed the geographical distribution of suitable climatic and edaphic conditions - or

254 habitat, as defined by these particular dimensions of the niche - for each of the target tree

255 species, following an ensemble procedure (Araújo \& New 2007) with the BIOMOD 1.1

256 modelling package (Thuiller et al. 2009) implemented in R (R Development Core Team 2010).

257 We considered both a baseline period (1961-1990) and a future period (2071-2100, hereafter

258 referred to as 2080).

259 We used species occurrence data and environmental predictors to build species

260 distribution models using eight modelling techniques: three regression methods (generalized

261 additive models, GAM; generalized linear models, GLM; multivariate adaptive regression

262 splines, MARS), two classification methods (mixture discriminant analysis, MDA; classification 
263 tree analysis, CTA) and three machine learning methods (artificial neural networks, ANN;

264 generalized boosted models, GBM; random forest, RF). All models were produced using default

265 BIOMOD parameters where possible (Thuiller et al. 2009). Further parameters were as follows:

266 GLMs were generated using quadratic terms and a stepwise procedure with the AIC criteria;

267 GAMs were generated with a spline function with three degrees of smoothing; GBMs were built

268 with a maximum of 2,000 trees; ANNs were produced with five cross-validations (see Marmion

269 et al. 2009) for further details on these modelling techniques). For each species, we built the

270 eight species distribution models using a random subset of data containing $70 \%$ of the $20 \times 20$ -

$271 \mathrm{~km}$ cells (i.e., 4,493 cells). We used the remaining 30\% (i.e., 1,925 cells) to evaluate the

272 predictive performance of the models. We repeated this split-sample procedure ten times, thus

273 calibrating 80 different statistical models for each species. We simulated suitability under

274 climate change (future suitability) by projecting each of the 80 projections under each of the

275 seven climate simulations for 2080. This generated a total of 560 probabilities

276 (ten repetitions $\mathrm{x}$ eight modelling techniques $\mathrm{x}$ seven climate simulations) of habitat suitability

277 for each species for the 2080 period. We combined the different probabilities of habitat

278 suitability $(\mathrm{P})$ based on the area under the receiver-operating characteristic (ROC) curve (AUC)

279 values; we assigned the AUC values from each modelling technique as the weights of the

280 weighted average in order to enhance the contributions of models with higher performance

281 values:

282

$W A P_{i_{\text {baseline }}}=\frac{\sum_{j=1}^{8} \sum_{k=1}^{10}\left(A U C_{j k} \times P_{i j k}\right)}{\sum_{j=1}^{8} \sum_{k=1}^{10}\left(A U C_{j k}\right)}$

283

$$
W A P_{i_{2080}}=\frac{\sum_{j=1}^{8} \Sigma_{k=1}^{10} \Sigma_{l=1}^{7}\left(A U C_{j k} \times P_{i j k l}\right)}{7 \times \Sigma_{j=1}^{8} \Sigma_{k=1}^{10}\left(A U C_{j k}\right)}
$$


285 grid cell $(1, \ldots, 6418), j$ is the modelling technique (GAM, GLM, MARS, CTA, MDA, ANN,

286 GBM, RF), $k$ is the repetition $(1, \ldots, 10)$ and $l$ is the climate simulation $(1, \ldots, 7)$. Averaged

287 projections resulted in a single projection at each grid cell for each species (hereafter referred as

288 the "average model") for the baseline period $\left(W A P_{i_{\text {baseline }}}\right.$;eq. 1$)$ and the 2080 period

$289\left(W A P_{i_{2080}} ;\right.$ eq. 2$)$. This method is considered to be more robust than other model fusion methods

290 or single model projections (Marmion et al. 2009b).

\section{Transforming probabilities of suitability to binary values}

292 To transform continuous probabilities of suitability into binary (0/1) values, we calculated a

293 common threshold (cut-off) value for both the baseline period and the 2080 period using a binary

294 vector of observed occurrence and a vector of probability of occurrence from the average model

$295\left(W A P_{i_{2080}}\right)$. We searched for the threshold which jointly maximized sensitivity and specificity

296 (Liu et al. 2005). This approach is considered among the most reliable for choosing a threshold

297 (Freeman \& Moisen 2008).

\section{Model evaluation}

299 The predictive model performance was evaluated using area under the receiver operating

300 characteristic curve (AUC; Fielding \& Bell 1997) as an accuracy measure. The area under the

301 ROC function (AUC) is usually taken to be an important index because it provides a single

302 measure of overall accuracy that is not dependent upon a particular threshold. Suggested AUC

303 values for classifying the accuracy of models using AUC are: $0.90-1.00=$ excellent; $0.80-$

$3040.9=$ good; $0.70-0.80=$ fair; $0.60-0.70=$ poor; $0.50-0.60=$ fail (e.g., Virkkala et al., 2010

305 adapted from Swets, 1988). Sensitivity (true positive fraction) and specificity (false positive

306 fraction) values were also reported for each species (Lobo et al. 2008). 
307 Agreement between the average future projection in each cell and the single projections

308 To measure the level of confidence in our average future projection for a given cell, we also

309 calculated the percentage of the 560 single projections for that cell that agreed with the average

310 projection (hereafter referred as "agreement value").

\section{Identifying vulnerable habitats under future climates}

312 We focused on Quebec's productive forest territory to evaluate whether predicted future

313 conditions remained suitable for a species within its baseline range. For this purpose, the baseline

314 range of a species was defined as the set of grid cells within Quebec productive forests where the

315 baseline average model predicted a suitable habitat $\left(W A P_{i_{\text {baseline }}} \geq\right.$ threshold value), as defined

316 by climatic, edaphic and topographic variables. Note that a 'suitable habitat' does not necessarily

317 mean an 'optimal habitat', since a species can be found on sites with suboptimal conditions.

318 Cells modelled as suitable habitat under baseline climatic conditions, but which became

319 unsuitable under future climate conditions, were classified as unsuitable habitat (UH). Cells

320 modelled as 'suitable' under both baseline and future climate further subdivided as:

321 Less Suitable Habitat (LSH):

322

$\left[W A P_{i 2080}-W A P_{i_{\text {baseline }}}<0 \&\left|W A P_{i 2080}-W A P_{i_{\text {baseline }}}\right| \geq 0.15\right]$

323 Persistent Habitats (PH):

324

$\left[W A P_{i 2080}-W A P_{i_{\text {baseline }}}<0 \quad \&\left|W A P_{i 2080}-W A P_{i_{\text {baseline }}}\right|<0.15\right]$

325

OR $\left[W A P_{i 2080}-W A P_{i_{\text {baseline }}} \geq 0\right]$

LSH reflects predicted probabilities of habitat suitability that decrease over time, but not

327 to the point of unsuitability like UH. We used the threshold of a $15 \%$ change of probabilities of

328 habitat suitability $\left(W A P_{i 2080}-W A P_{i_{\text {baseline }}}\right)$ to select the proper subcategory for each cell. This 
329 threshold was chosen after examining spatial predictions for 2050 and comparing them with

330 predictions for 2080 . The majority of cells classified as less suitable at the $15 \%$ threshold in 2050

331 became unsuitable in 2080 . A sensitivity analysis, where the threshold value varied from $5 \%$ to

$33225 \%$, showed how forecasts are affected when this value changes (Fig. S7).

333 For each species, we reported trends in relation to the entire productive forest territory,

334 the baseline range of the species in Quebec, and each of five vegetation domains.

\section{RESULTS}

\section{Model evaluation}

337 Overall, all the models performed well and showed good capacity on species prediction as

338 accuracies showed high values (Table S3). The AUC values of the average models ranged from

3390.916 (sugar maple) to 0.984 (for balsam fir), for a mean value of $0.958 \pm 0.029$. We also

340 determined that the largest part of variability in future projections was explained by the SDMs

341 (Fig. S8).

\section{Assessing risk under future climate}

343 Species are presented in order of decreasing importance in the study area (as measured by size of

344 their baseline range in Quebec's productive forest).

345 Black spruce (Table 2; Fig. 2A)

346 The baseline range for black spruce in the study area essentially covers all five bioclimatic

347 domains. Overall, 78\% of the baseline range of black spruce in Quebec's productive forest is

348 projected to shift towards unsuitable (18\%) or less suitable $(60 \%)$ conditions compared to

349 baseline conditions (agreement value $=68 \%$ ). Shifts in suitability are projected largely within the

350 sugar maple domain ( $89 \%$ of baseline spruce habitat in that domain shifting to unsuitable), the 
351 balsam fir-yellow birch domain (13\% shifting to unsuitable), and the balsam fir-white birch

352 domain ( $2 \%$ shifting to unsuitable). Moreover, all the remaining baseline habitats in these

353 domains are projected to become less suitable for black spruce compared to baseline climatic

354 conditions. In the spruce--moss domain, $52 \%$ of suitable habitats are projected to become less

355 suitable for the species.

356 Balsam fir (Table 2; Fig. 2B)

357 The baseline range for balsam fir covers more than 97\% of Quebec's productive forests. Overall,

$35859 \%$ of the baseline range of balsam fir is projected to shift towards unsuitable $(21 \%)$ or less

359 suitable $(38 \%)$ climatic conditions (agreement value $=69 \%)$ with climate change. Essentially, all

360 baseline sites over the entire sugar maple domains and the balsam fir-yellow birch domain are

361 projected to become unsuitable or less suitable. Further north, in the balsam fir-white birch

362 domain, shifts towards unsuitability are projected on $1 \%$ of the range, while less suitable

363 conditions are projected on another $87 \%$.

364 White birch (Table 2; Fig. 2C)

365 White birch is widely distributed in the study area with a baseline range covering $94 \%$ of

366 Quebec's productive forests. Overall, 62\% of the baseline range of balsam fir is projected to shift

367 towards unsuitable $(14 \%)$ or less suitable $(48 \%)$ climatic conditions (agreement value $=71 \%$ )

368 with climate change. In the sugar maple domains, unsuitability is projected on $63 \%$ of the

369 baseline range, with the remainder projected as less suitable compared to baseline conditions.

370 Only $2 \%$ of habitats shifts towards unsuitability in the balsam fir-yellow birch domain, but less

371 suitable habitats are projected in $67 \%$ of the balsam fir-yellow birch domain, $79 \%$ of the balsam

372 fir-white birch domain, and $15 \%$ of the spruce-moss domain. 
373 Yellow birch (Table 2; Fig. 2D)

374 The baseline range for yellow birch covers 44\% of Quebec's productive forests. Shifts towards

375 unsuitability (5\%) or less suitability (19\%) are projected over $24 \%$ of the baseline range

376 (agreement value $=78 \%$ ). All unsuitable areas are in the sugar maple domains $(13 \%)$, as are

377 most habitats projected as less suitable (48\%).

378 Sugar maple (Table 2; Fig. 2E)

379 The baseline range of sugar maple covers 31\% of Quebec's productive forests, essentially in the

380 south. Shifts towards unsuitability $(8 \%)$ or less suitability $(1.3 \%)$ are projected for $9.3 \%$ of the

381 sugar maple baseline range (agreement value $=60 \%$ ). All sites shifting to unsuitable conditions

382 are in the sugar maple domains. The more northern domains are predicted to maintain their

383 current habitats for sugar maple.

384 Discussion

385 Most studies linking climate change with species distribution models emphasize the

386 potential for major shifts in species ranges and a massive reorganisation of biodiversity. Our

387 study is no exception but here we focus on areas where species are projected to become at risk of

388 climate change-related stress to help define adaptation strategies. We define 'risk' as a function

389 of the probability of an event (climate becoming unsuitable or less suitable for a species as

390 projected) and the severity of its consequences (FAO 2007; Leung et al. 2012). Whereas one can

391 rightly argue that there is still much uncertainty in assessing probability of species occurrence in

392 a changing climate, there is no doubt that the consequences of habitat decline at a particular

393 location can be highly significant for ecosystems and economies that depend on, or are defined

394 by these species. Risk assessment through climate/species models, therefore, has at least two

395 immediate benefits. Just as for climate projections, it can help draw attention of policy makers, 
396 forest management agencies, and the public in general on the sheer magnitude of projected

397 climate change effects on biodiversity. Secondly, because models are spatially-explicit and

398 species-specific, they can help target monitoring efforts, especially when resources are scarce,

399 and potentially inform adaptation strategies.

400 The consequences of an unsuitable climate on species can be associated with a range of

401 processes directly or indirectly related to climate change, including increased physiological stress

402 induced by heat or drought (Anderegg et al. 2015; Park Williams et al. 2013; Sun et al. 2015; Wu

403 et al. 2012), increased vulnerability to pest and disease outbreaks (Creeden et al. 2014; DeRose

404 et al. 2013; Fierravanti et al. 2015), competition from other species (Blois et al. 2013; Brooker

405 2006; Carón et al. 2015; Dukes et al. 2009; Meier et al. 2012) or herbivory (Svenning \& Sandel

406 2013), and increased climate-mediated frequency of fires or destructive weather events

407 (Bergeron et al. 2010; Terrier et al. 2013). However, the precise pathways through which climate

408 change will affect a particular forest remains difficult to predict, as is the attribution of any

409 particular event to climate change. Based on the proportion of their baseline range that is

410 projected to become unsuitable, our target species rank as follows, in decreasing order of

411 vulnerability: balsam fir (21\%), black spruce (18\%), white birch (14\%), sugar maple (8\%), and

412 yellow birch (5\%). In the $185,000-\mathrm{km}^{2}$ area where the baseline ranges of all five species intersect,

413 at least three species - and, in the southernmost part of the study area, all five of them - are

414 projected to be at some risk of climate-related stress (Fig. 3). This represents a significant

415 proportion of Quebec forests and suggests that species that have traditionally defined whole

416 regional vegetation assemblages could become less characteristic of these regions. Forest decline

417 would have, as well, consequences on the value of forest land (Hanewinkel et al. 2012). 
419 retract from their southern margins in the study area with warming. Biotic interactions are often

420 emphasized over climate in determining southern range edges (Normand et al. 2009; Sunday et

421 al. 2012), and so this raises the question of whether competitive processes mediated by species

422 traits over novel climatic conditions will help shift dominance of species locally. For instance,

423 balsam fir is more fire-sensitive than black spruce and shifts in fire regime in the northern boreal

424 forests over millennia have shifted dominance towards one species or the other, with warm and

425 wet conditions favouring balsam fir over black spruce (Ali et al. 2008; Couillard et al. 2013).

426 Moreover, the observed northward migration of pests, such as spruce budworms, facilitated by

427 climate change is also contributing to increase the intensity and frequency of outbreaks in some

428 areas. Whereas balsam fir is currently considered a more suitable host than black spruce, this

429 may change when the budworm hits spruce-dominated forests (Pureswaran et al. 2015).

430 Warming experiments can show direct physiological effect on individual trees, but it is

431 not always clear how warming can influence whole species assemblages over a range of soil

432 conditions. Increased frequency and intensity of droughts, for instance, have led to negative

433 effects on the duration of xylogenesis and the production of xylem cells in balsam fir in warming

434 experiments (D'Orangeville et al. 2013). For sugar maple, the observation that adverse winter

435 and spring conditions in southern sites negatively impact maple syrup production may provide

436 early indication for warming effect (Duchesne \& Houle 2014). As decreasing growth rates can

437 precede mortality, an even stronger signal comes from the observation of widespread decreasing

438 growth rate for sugar maple documented in the Adirondacks (Bishop et al. 2015). While

439 underlying mechanisms have to be clarified, these observations are in agreement with niche

440 model projections in the eastern U.S. (Iverson et al. 2008). 
There is uncertainty in model projections because of uncertainty in climate simulations,

442 statistical models, and the non-linear responses of ecosystems and species. Climate simulations

443 are improving (Flato et al. 2013) and the limitations of different statistical models are well

444 recognised (Marmion et al. 2009a). These limitations are often taken into account, for instance

445 by using consensus approaches across several statistical and climate models (Guo et al. 2015;

446 Wang et al. 2016). The level of agreement among our projections was generally high (averaging

$44775 \%$ ), raising confidence in our results given the data available. Nevertheless, the main source of

448 uncertainty may rest not so much in the methodology used than in the model assumptions. There

449 is no doubt that climate is a strong predictor of site occupancy patterns for species, particularly at

450 broad spatial scale (Pearson \& Dawson 2003). What remains unclear, however, is the extent to

451 which climate mainly determines species range boundaries and whether current distribution

452 patterns really capture the physiological limits of species (Brown \& Vellend 2014; García-

453 Valdés et al. 2015; Nowacki \& Abrams 2015; Paul et al. 2014). The availability of suitable

454 conditions other than climate, postglacial dispersal limitations, or competition can all contribute

455 to species not filling their available climatic niche (Sinclair et al. 2010). Coupling physiological

456 models or trait information with correlative range models can help refine projections (Iverson et

457 al. 2011; Talluto et al. 2016), providing that physiological models capture species responses

458 outside the range of conditions represented by species presence-absence data. If there is, for

459 instance, evidence for climatically suitable sites colder than those currently captured by the

460 observed species' range, the consequences may be minimal on risk assessment related to

461 warming. If, on the other hand, there is evidence for climatically suitable sites warmer than those

462 currently defined by a species' range - or greater tolerance to warming than previously thought ,

463 future projections are likely to overestimate the risk of climate change on species distribution. 
464 Since species interactions also influence species distribution - but are somewhat integrated in

465 models based on a species' realised niche, another unresolved issue is how communities will

466 reassemble. Disagreements as to the geographical extent of climate vulnerability are likely to

467 persist until monitoring and field evidence clearly show trends in support of (or in disagreement

468 with) projections in a given region. Models can only point towards species or areas at risk for

469 greater scrutiny and, most of all, provide incentive for developing and testing adaptation

470 strategies.

471 If projections in this study question the future relevance of the current ecological

472 classification of the forest landscape, they also raise important issues regarding the forest

473 management regime, especially under the assumption that an ecosystem is defined by a relatively

474 stable climate and substrate. The ecological principles that underlie current ecosystem-based

475 management emphasize the need to reduce the differences between natural and managed

476 landscapes (Gauthier et al. 2009). They imply that sustainable forest management practices

477 should aim for a desired composition and age structure. This becomes quite a challenge if the

478 'target composition' is moving fast under a new climate regime (Dhital et al. 2015; Mori et al.

479 2013). Therefore, the greatest challenges in coming years will be to manage rapid transitions of

480 forests towards other, largely unknown, 'steady-states'. As a result, the adaptation literature has

481 repeatedly highlighted the need to move from a paradigm of preserving current conditions or

482 restoring 'historical fidelity' to one of managing for novel ecosystems that may differ in

483 composition, structure, and/or function (Hobbs et al. 2009). Models provide some indications of

484 where the challenges could be the greatest, and whether or not species at risk are worth

485 maintaining at specific locations under a shifting climate. Publicly managed forests in the study

486 area, for instance, are restored to production largely by prioritizing practices that protect the 
487 established regeneration. Where regeneration is insufficient, as may increasingly be the case on

488 sites that we identified as 'at risk', reforestation may be carried out. However, the choice of

489 species is for the most part still made under the assumption that suitable conditions in this

490 century will be similar to the ones in recent history. New practices are being tested to maximize

491 forest resiliency while taking into account transition states, for instance by helping shift

492 composition (including genetic variability) towards species or individuals adapted to the new

493 climate regime (Breed et al. 2012; Koralewski et al. 2015; Park Williams et al. 2014). As well,

494 maintaining biodiverse (both in terms of composition and age structure) forests and landscapes

495 could provide some insurance against instability (Churchill et al. 2013; Thompson et al. 2009).

496 Our study area covers large regions where forest logging, especially of softwood stands,

497 contributes significantly to the economy. Forests provide habitats and contribute to global carbon

498 storage. Be it with species distribution models (Hufnagel \& Garamvolgyi 2014), more detailed

499 process-based models (Zolkos et al. 2014), warming experiments (Dulamsuren et al. 2013) or

500 field evidence (Dudley et al. 2015; Girardin et al. 2014; Worrall et al. 2013), all attempts to

501 translate climate simulations into forest patterns converge towards the same message: trees could

502 be at risk of maladaptation over a remarkably large proportion of their baseline range in this

503 century. Sustaining yield could become increasingly difficult in these conditions. Reforestation

504 planning will have to take into account climate trajectory and maps indicating areas at risk.

505 Although it will be tempting to log declining forests, it will be as important to preserve reference

506 areas under natural disturbances in order to understand 'natural' dynamics and adapt

507 management options accordingly. New engagement rules with the forest industry, which may see

508 areas at risk as opportunities for 'salvage logging', will be needed. 
510 fronts: 1) Risk assessment, including the targeted monitoring of areas at risk, in order to

511 understand forest dynamics under changing conditions. Quebec has the advantage of having

512 established a large network of forest sites under observation since the 1970s (Ministère des

513 Forêts de la Faune et des Parcs 2014). Assessment of climate change-related risk is probably

514 where most research efforts have focused so far, but there is still a need to better identify and

515 target areas and species at risk. 2) Risk communication with stakeholders, decision makers, and

516 the public in general. During the last decade, a great deal of work has been done to provide

517 conceptual frameworks and provide new approaches and tools for decision making under

518 uncertainty (Janowiak et al. 2014). In Quebec, the recent publication of the results of a large

519 study involving scientists and stakeholders on the impacts of climate change on Quebec

520 biodiversity is a positive step in that direction (Berteaux et al. 2014). When communicating risk,

521 it is indeed important to indicate the uncertainty inherent in all projections. However, the

522 scientific emphasis on uncertainty has also been seen as possibly deterring from early action

523 regarding climate change policies (Morton et al. 2011). 3) Risk management, which involves

524 basing decisions on the best information available. This may be the most challenging aspect.

525 Comparing the outcomes of alternative management scenarios in relation to predicted responses

526 of forest to climate change could inform management decisions (Messier et al. 2016). If they are

527 not already in place, adaptation strategies are needed, if only to allow sufficient time for forest

528 ecosystems and regional forest economies to adapt. In spite of their well-recognised limitations,

529 regionally-explicit risk assessment approaches, such as the one used here, currently remain one

530 of the best options to convey the need for climate policies and forest management adaptation

531 strategies. 


\section{Acknowledgements}

533 The authors thank Travis Logan and Ouranos for providing the climate-scenario data, Marie-

534 Claude Lambert and Nicolas Casajus for assisting with statistical analyses, Denise Tousignant 535 for scientific edition, and reviewers for their helpful suggestions. 


\section{Literature Cited}

537 Ali AA, Asselin H, Larouche AC, Bergeron Y, Carcaillet C, and Richard PJH. 2008. Changes in

538 fire regime explain the Holocene rise and fall of Abies balsamea in the coniferous forests of

539 western Quebec, Canada. Holocene 18:693-703. 10.1177/0959683608091780

540 Anderegg WRL, Flint A, Huang C-y, Flint L, Berry JA, Davis FW, Sperry JS, and Field CB.

541 2015. Tree mortality predicted from drought-induced vascular damage. Nature Geoscience

542 advance online publication. 10.1038/ngeo2400

543 http://www.nature.com/ngeo/journal/vaop/ncurrent/abs/ngeo2400.html\#supplementary-

544 information

545 Araújo MB, and New M. 2007. Ensemble forecasting of species distributions. Trends in Ecology

546 and Evolution 22:42-47. 10.1016/j.tree.2006.09.010

547 Araújo MB, and Peterson AT. 2012. Uses and misuses of bioclimatic envelope modeling.

$548 \quad$ Ecology 93:1527-1539. http://dx.doi.org/10.1890/11-1930.1

549 Aubin I, Garbe CM, Colombo S, Drever CR, McKenney DW, Messier C, Pedlar JH, Saner MA,

550 Venier LA, Wellstead AM, Winder R, Witten E, and Ste-Marie C. 2011. Why we disagree

551 about assisted migration: Ethical implications of a key debate regarding the future of

552 Canada's forests. The Forestry Chronicle 87:755-765.

553 Barbet-Massin M, Thuiller W, and Jiguet F. 2010. How much do we overestimate future local

554 extinction rates when restricting the range of occurrence data in climate suitability models?

$555 \quad$ Ecography 33:878-886. 10.1111/j.1600-0587.2010.06181.x

556 Beauregard F, and de Blois S. 2014. Beyond a climate-centric view of plant distribution: edaphic

557 variables add value to distribution models. PLoS One 9:e92642.

$558 \quad$ 10.1371/journal.pone.0092642 
559 Bergeron Y, Cyr D, Girardin M, and Carcaillet C. 2010. Will climate change drive 21st century

560 burn rates in Canadian boreal forest outside of its natural variability: collating global climate

561 model experiments with sedimentary charcoal data. International Journal of Wildland Fire

$562 \quad 19: 1127-1139$.

563 Berteaux D, Casajus N, and De Blois S. 2014. Changements climatiques et biodiversité du

564 Québec : vers un nouveau patrimoine naturel. Québec: Les Presses de l'Université du 565 Québec.

566 Bishop DA, Beier CM, Pederson N, Lawrence GB, Stella JC, and Sullivan TJ. 2015. Regional 567 growth decline of sugar maple (Acer saccharum) and its potential causes. Ecosphere 6:14.

$568 \quad 10.1890 / \mathrm{es} 15-00260.1$

569 Blois JL, Zarnetske PL, Fitzpatrick MC, and Finnegan S. 2013. Climate change and the past, 570 present, and future of biotic interactions. Science 341:499-504. 10.1126/science.1237184

571 Boisvert-Marsh L, Périé C, and de Blois S. 2014. Shifting with climate? Evidence for recent

572 changes in tree species distribution at high latitudes. Ecosphere 5:83. 10.1890/es14-00111.1

573 Breed MF, Stead MG, Ottewell KM, Gardner MG, and Lowe AJ. 2012. Which provenance and 574 where? Seed sourcing strategies for revegetation in a changing environment. Conservation $575 \quad$ Genetics 14:1-10. 10.1007/s10592-012-0425-z

576 Brooker RW. 2006. Plant-plant interactions and environmental change. New Phytologist $577 \quad$ 171:271-284. 10.1111/j.1469-8137.2006.01752.x

578 Brown CD, and Vellend M. 2014. Non-climatic constraints on upper elevational plant range

579 expansion under climate change. Proceedings Biological sciences / The Royal Society

$580 \quad 281: 20141779.10 .1098 / \mathrm{rspb} .2014 .1779$ 
581 Carón MM, De Frenne P, Brunet J, Chabrerie O, Cousins SAO, Decocq G, Diekmann M, Graae

582 BJ, Heinken T, Kolb A, Lenoir J, Naaf T, Plue J, Selvi F, Wulf M, and Verheyen K. 2015.

583 Divergent regeneration responses of two closely related tree species to direct abiotic and

584 indirect biotic effects of climate change. Forest Ecology and Management 342:21-29.

$585 \quad$ 10.1016/j.foreco.2015.01.003

586 Casajus N., Périé C, Logan T, Lambert M-C, de Blois S, and Berteaux D. 2016. An objective 587 approach to select climate scenarios when projecting species distributions under climate $588 \quad$ change. PlosOne 11:e0152495.

589 Churchill DJ, Larson AJ, Dahlgreen MC, Franklin JF, Hessburg PF, and Lutz JA. 2013.

590 Restoring forest resilience: from reference spatial patterns to silvicultural prescriptions and 591 monitoring. Forest Ecology and Management 291:442-457. 10.1016/j.foreco.2012.11.007

592 Couillard P-L, Payette S, and Grondin P. 2013. Long-term impact of fire on high-altitude balsam 593 fir (Abies balsamea) forests in south-central Quebec deduced from soil charcoal. Canadian 594 Journal of Forest Research-Revue Canadienne De Recherche Forestiere 43:188-199. 10.1139/cjfr-2012-0414

596 Creeden EP, Hicke JA, and Buotte PC. 2014. Climate, weather, and recent mountain pine beetle 597 outbreaks in the western United States. Forest Ecology and Management 312:239-251.

$598 \quad$ 10.1016/j.foreco.2013.09.051

599 D'Orangeville L, Cote B, Houle D, and Morin H. 2013. The effects of throughfall exclusion on $600 \quad$ xylogenesis of balsam fir. Tree Physiology 33:516-526. 10.1093/treephys/tpt027

601 Davis BM, Shaw RG, and R. EJ. 2005. Evolutionary responses to changing climate. Ecology $602 \quad 86: 1704-1714$ 
603 DeRose RJ, Bentz BJ, Long JN, and Shaw JD. 2013. Effect of increasing temperatures on the 604 distribution of spruce beetle in Engelmann spruce forests of the Interior West, USA. Forest 605 Ecology and Management 308:198-206. 10.1016/j.foreco.2013.07.061

606 Dhital N, Raulier F, Bernier PY, Lapointe-Garant M-P, Berninger F, and Bergeron Y. 2015.

607 Adaptation potential of ecosystem-based management to climate change in the eastern 608 Canadian boreal forest. Journal of Environmental Planning and Management 58:2228-2249. $609 \quad 10.1080 / 09640568.2014 .978079$

610 Diffenbaugh NS, and Field CB. 2013. Changes in ecologically critical terrestrial climate 611 conditions. Science 341:486-492. 10.1126/science.1237123

612 Diffenbaugh NS, and Scherer M. 2011. Observational and model evidence of global emergence 613 of permanent, unprecedented heat in the 20 (th) and 21(st) centuries. Climatic Change $614 \quad 107: 615-624.10 .1007 / \mathrm{s} 10584-011-0112-y$

615 Duchesne L, and Houle D. 2014. Interannual and spatial variability of maple syrup yield as 616 related to climatic factors. Peerj 2:e428. 10.7717/peerj.428

617 Dudley MM, Burns KS, and Jacobi WR. 2015. Aspen mortality in the Colorado and southern 618 Wyoming Rocky Mountains: extent, severity, and causal factors. Forest Ecology and 619 Management 353:240-259. 10.1016/j.foreco.2015.06.002

620 Dukes JS, Pontius J, Orwig D, Garnas JR, Rodgers VL, Brazee N, Cooke B, Theoharides KA, 621 Stange EE, Harrington R, Ehrenfeld J, Gurevitch J, Lerdau M, Stinson K, Wick R, and Ayres 622 M. 2009. Responses of insect pests, pathogens, and invasive plant species to climate change 623 in the forests of northeastern North America: What can we predict? Canadian Journal of $624 \quad$ Forest Research 39:231-248. 10.1139/x08-171 
625 Dulamsuren C, Wommelsdorf T, Zhao F, Xue Y, Zhumadilov BZ, Leuschner C, and Hauck M.

626 2013. Increased summer temperatures reduce the growth and regeneration of Larix sibirica in

627 southern boreal forests of Eastern Kazakhstan. Ecosystems 16:1536-1549. 10.1007/s10021-

$628 \quad 013-9700-1$

629 Elith J, and Leathwick JR. 2009. Species distribution models: ecological explanation and 630 prediction across space and time. Annual Review of Ecology, Evolution, and Systematics

$631 \quad 40: 677-697.10 .1146 /$ annurev.ecolsys.110308.120159

632 FAO. 2007. Glossary of phytosanitary terms. International standards for phytosanitary measures.

633 Publication No. 5. Rome, IT.

634 Fielding AH, and Bell JF. 1997. A review of methods for the assessment of prediction errors in 635 conservation presence/absence models. Environmental Conservation 24:38-49.

636 Fierravanti A, Cocozza C, Palombo C, Rossi S, Deslauriers A, and Tognetti R. 2015.

637 Environmental-mediated relationships between tree growth of black spruce and abundance of

638 spruce budworm along a latitudinal transect in Quebec, Canada. Agricultural and Forest

639 Meteorology 213:53-63. 10.1016/j.agrformet.2015.06.014

640 Flato G, Marotzke J, Abiodun B, Braconnot P, Chou SC, Collins W, Cox P, Driouech F, Emori

641 S, Eyring V, Forest C, Gleckler P, Guilyardi E, Jakob C, Kattsov V, Reason C, and

642 Rummukainen M. 2013. Evaluation of climate models. In: Stocker TF, Qin D, Plattner G-K,

643 Tignor M, Allen SK, Boschung J, Nauels A, Xia Y, Bex V, and Midgley GF, eds. Climate

644 change 2013: The physical science basis contribution of working group I to the fifth

645 assessment report of the intergovernmental panel on climate change. Cambridge, United

646 Kingdom and New York, NY, USA: Cambridge University Press. 
647 Franklin J. 2013. Species distribution models in conservation biogeography: developments and $648 \quad$ challenges. Diversity and Distributions 19:1217-1223. 10.1111/ddi.12125

649 Freeman EA, and Moisen GG. 2008. A comparison of the performance of threshold criteria for 650 binary classification in terms of predicted prevalence and kappa. Ecological Modelling $651 \quad 217: 48-58.10 .1016 / j$. .ecolmodel .2008 .05 .015

652 García-Valdés R, Svenning J-C, Zavala MA, Purves DW, Araújo MB, and Saura S. 2015.

653 Evaluating the combined effects of climate and land-use change on tree species distributions. $654 \quad$ Journal of Applied Ecology 52:902-912. 10.1111/1365-2664.12453

655 Gauthier S, Bernier P, Kuuluvainen T, Shvidenko AZ, and Schepaschenko DG. 2015. Boreal 656 forest health and global change. Science 349:819-822. 10.1126/science.aaa9092

657 Gauthier S, Vaillancourt M-A, Leduc A, De Grandpré L, Kneeshaw D, Morin H, Drapeau P, and 658 Bergeron Y. 2009. Ecosystem management in the boreal forest. Québec, Canada: Les Presses 659 de l'Université du Québec.

660 Girardin M, Guo XJ, de Jong R, Kinnard C, Bernier P, and Raulier F. 2014. Unusual forest 661 growth decline in boreal North America covaries with the retreat of Arctic sea ice. Global 662 Change Biology 20:851-866. doi: 10.1111/gcb.12400

663 Guo C, Lek S, Ye S, Li W, Liu J, and Li Z. 2015. Uncertainty in ensemble modelling of large664 scale species distribution: Effects from species characteristics and model techniques. 665 Ecological Modelling 306:67-75. 10.1016/j.ecolmodel.2014.08.002

666 Hanewinkel M, Cullmann DA, Schelhaas M-J, Nabuurs G-J, and Zimmermann NE. 2012.

667 Climate change may cause severe loss in the economic value of European forest land. Nature 668 Climate Change 3:203-207. 10.1038/nclimate1687 
669 Hobbs RJ, Higgs E, and Harris JA. 2009. Novel ecosystems: implications for conservation and

670 restoration. Trends in Ecology and Evolution 24:599-605. 10.1016/j.tree.2009.05.012

671 Hufnagel L, and Garamvolgyi A. 2014. Impacts of climate change on vegetation distribution

672 NO. 2-Climate change induced vegetation shifts in the new world. Applied Ecology and

673 Environmental Research 12:355-422.

674 Iverson LR, Prasad AM, Matthews SN, and Peters M. 2008. Estimating potential habitat for 134

675 eastern US tree species under six climate scenarios. Forest Ecology and Management

$676 \quad 254: 390-406.10 .1016 /$ j.foreco.2007.07.023

677 Iverson LR, Prasad AM, Matthews SN, and Peters MP. 2011. Lessons learned while integrating

678 habitat, dispersal, disturbance, and life-history traits into species habitat models under climate

679 change. Ecosystems 14:1005-1020. 10.1007/s10021-011-9456-4

680 Janowiak MK, Swanston CW, Nagel LM, Brandt LA, Butler PR, Handler SD, Shannon PD,

681 Iverson LR, Matthews SN, Prasad A, and Peters MP. 2014. A Practical Approach for

682 Translating Climate Change Adaptation Principles into Forest Management Actions. Journal

683 of Forestry 112:424-433. 10.5849/jof.13-094

684 Jansen E, J., Overpeck KR, Briffa J-C, Duplessy FJ, Masson-Delmotte V, Olago D, Otto-

685 Bliesner B, Peltier WR, Rahmstorf S, Ramesh R, Raynaud D, Rind D, Solomina O, Villalba

686 R, and Zhang D. 2007. Palaeoclimate. In: Solomon S, Manning M, Chen Z, Marquis M,

687 Averyt KB, Tignor M, and Miller HL, eds. Climate change 2007: The physical science basis

688 Contribution of Working Group I to the Fourth Assessment Report of the Intergovernmental

689 Panel on Climate Change. Cambridge, United Kingdom and New-York, NY, USA:

$690 \quad$ Cambridge University Press. 
691 Koralewski TE, Wang H-H, Grant WE, and Byrama TD. 2015. Plants on the move: assisted 692 migration of forest trees in the face of climate change. Forest Ecology and Management $693 \quad 344: 30-37$.

694 Lafleur B, Paré D, Munson AD, and Bergeron Y. 2010. Response of northeastern North 695 American forests to climate change: Will soil conditions constrain tree species migration? 696 Environmental Reviews 18:279-289. 10.1139/a10-013

697 Landscape Change Research Group. 2014. Climate change atlas. Delaware, OH.: Northern 698 Research Station, U.S. Forest Service, http://www.nrs.fs.fed.us/atlas.

699 Leung B, Roura-Pascual N, Bacher S, Heikkila J, Brotons L, Burgman MA, Dehnen-Schmutz K,

700 Essl F, Hulme PE, Richardson DM, Sol D, Vila M, and Rejmanek M. 2012. TEASIng apart

701 alien species risk assessments: a framework for best practices. Ecology letters 15:1475-1493. $702 \quad 10.1111 /$ ele.12003

703 Little EL, Jr.,. 1971. Atlas of United States trees. Misc. Pub. 1146., Washington, D.C.: U.S. :

704 Department of Agriculture.

705 Liu C, Berry PM, Dawson TP, and Pearson RG. 2005. Selecting thresholds of occurrence in the 706 prediction of species distributions. Ecography 28:385-393.

707 Lobo JM, Jiménez-Valverde A, and Real R. 2008. AUC: a misleading measure of the 708 performance of predictive distribution models. Global Ecology and Biogeography 17:145$709 \quad 151.10 .1111 / \mathrm{j} .1466-8238.2007 .00358 . x$

710 Logan T, Charron I, Chaumont D, and Houle D. 2011. Atlas de scénarios climatiques pour la 711 forêt québécoise. Quebec: Ouranos et MRNF. p 55 p + annexes. 
712 Marmion M, Luoto M, Heikkinen RK, and Thuiller W. 2009a. The performance of state-of-the-

713 art modelling techniques depends on geographical distribution of species. Ecological

$714 \quad$ Modelling 220:3512-3520. 10.1016/j.ecolmodel.2008.10.019

715 Marmion M, Parviainen M, Luoto M, Heikkinen RK, and Thuiller W. 2009b. Evaluation of

716 consensus methods in predictive species distribution modelling. Diversity and Distributions

$717 \quad$ 15:59-69. 10.1111/j.1472-4642.2008.00491.x

718 Meehl GA, Covey C, Taylor KE, Delworth T, Stouffer RJ, Latif M, McAvaney B, and Mitchell

719 JFB. 2007. THE WCRP CMIP3 multimodel dataset: A new era in climate change research.

720 Bulletin of the American Meteorological Society 88:1383-1394. 10.1175/bams-88-9-1383

721 Meier ES, Lischke H, Schmatz DR, and Zimmermann NE. 2012. Climate, competition and

722 connectivity affect future migration and ranges of European trees. Global Ecology and

$723 \quad$ Biogeography 21:164-178. 10.1111/j.1466-8238.2011.00669.x

724 Messier C, Puettmann K, Filotas E, and Coates D. 2016. Dealing with non-linearity and

725 uncertainty in forest management. Current Forestry Reports 2:150-161. 10.1007/s40725-016-

$726 \quad 0036-x$

727 Ministère des Forêts de la Faune et des Parcs. 2014. Réseaux des placettes-échantillons

728 permanentes du Québec méridonal. In: forêts Sd, editor. Québec: Direction des inventaires

729 forestiers - Gouvernement du Québec. p 10.

730 Ministère des Ressources Naturelles. 2013. Le guide sylvicole du Québec, Tome 1, Les

731 fondements biologiques de la sylviculture: ouvrage collectif sous la supervision de B. Boulet

732 et M. Huot, Les Publications du Québec. 
733 Mori AS, Spies TA, Sudmeier-Rieux K, and Andrade A. 2013. Reframing ecosystem

734 management in the era of climate change: Issues and knowledge from forests. Biological

735 Conservation 165:115-127. 10.1016/j.biocon.2013.05.020

736 Morton TA, Rabinovich A, Marshall D, and Bretschneider P. 2011. The future that may (or may

737 not) come: How framing changes responses to uncertainty in climate change

738 communications. Global Environmental Change 21:103-109.

$739 \quad 10.1016 /$ j.gloenvcha.2010.09.013

740 Normand S, Treier UA, Randin C, Vittoz P, Guisan A, and Svenning JC. 2009. Importance of

741 abiotic stress as a range-limit determinant for European plants: insights from species

742 responses to climatic gradients. Global Ecology and Biogeography. Global Ecology and

743 Biogeography 18:437-449.

744 Nowacki GJ, and Abrams MD. 2015. Is climate an important driver of post-European vegetation

745 change in the Eastern United States? Global Change Biology 21:314-334. 10.1111/gcb.12663

746 Ouranos. 2015. Vers l'adaptation. Synthèse des connaissances sur les changements climatiques

747 au Québec. Partie 1 : Évolution climatique au Québec. Montréal, Québec: Ouranos.

748 Park Williams A, Puettmann K, Wilson E, Messier C, Kames S, and Dhar A. 2014. Can boreal

749 and temperate forest management be adapted to the uncertainties of 21st Century Climate

750 Change? Critical Reviews in Plant Sciences 33:251-285. 10.1080/07352689.2014.858956

751 Park Williams A, Allen CD, Macalady AK, Griffin D, Woodhouse CA, Meko DM, Swetnam

752 TW, Rauscher SA, Seager R, Grissino-Mayer HD, Dean JS, Cook ER, Gangodagamage C,

753 Cai M, and McDowell NG. 2013. Temperature as a potent driver of regional forest drought

754 stress and tree mortality. Nature Climate Change 3:292-297. 
755 http://www.nature.com/nclimate/journal/v3/n3/abs/nclimate1693.html\#supplementary-

756 information

757 Paul V, Bergeron Y, and Tremblay MF. 2014. Does climate control the northern range limit of 758 eastern white cedar (Thuja occidentalis L.)? Plant Ecology 215:181-194.

759 Pearson RG, and Dawson TP. 2003. Predicting the impacts of climate change on the distribution

760 of species: are bioclimate envelope models useful? Global Ecology and Biogeography

$761 \quad 12: 361-371$.

762 Price DT, Alfaro RI, Brown KJ, Flannigan MD, Fleming RA, Hogg EH, Girardin MP, Lakusta

763 T, Johnston M, McKenney DW, Pedlar JH, Stratton T, Sturrock RN, Thompson ID,

764 Trofymow JA, and Venier LA. 2013. Anticipating the consequences of climate change for

765 Canada's boreal forest ecosystems1. Environmental Reviews 21:322-365. 10.1139/er-2013-

$766 \quad 0042$

767 Pureswaran D, De Grandpré L, Paré D, Taylor A, Morin H, Régnière J, and Kneeshaw D. 2015.

768 Climate-induced changes in host tree-insect phenology may drive ecological state-shift in 769 boreal forests. Ecology 96:1480-1491.

770 R Development Core Team. 2010. R: A language and environement for statistical computing. R

$771 \quad$ Foundation for Statistical Computing.

772 Ray D, Morison J, and Broadmeadow M. 2010. Climate change: impacts and adaptation in 773 England's woodlands. Edinburgh, UK: Forestry Commission of England. p 16.

774 Renwick KM, and Rocca ME. 2015. Temporal context affects the observed rate of climate-

775 driven range shifts in tree species. Global Ecology and Biogeography 24:44-51.

$776 \quad 10.1111 /$ geb. 12240 
777 Rogelj J, Meinshausen M, and Knutti R. 2012. Global warming under old and new scenarios

778 using IPCC climate sensitivity range estimates. Nature Climate Change 2:248-253. DOI:

779 10.1038/NCLIMATE1385

780

SAS Institute Inc. . 2008. SAS/STAT® 9.2 User’s Guide. Cary, NC: SAS Institute Inc.

781 Savage J, and Vellend M. 2015. Elevational shifts, biotic homogenization and time lags in

782 vegetation change during 40 years of climate warming. Ecography 38:546-555.

783 10.1111/ecog.01131

784

Sinclair SJ, White MD, and Newell GR. 2010. How useful are species distribution models for managing biodiversity under future climates? Ecology and Society 15:art8.

Sun S, Sun G, Caldwell P, McNulty SG, Cohen E, Xiao J, and Zhang Y. 2015. Drought impacts on ecosystem functions of the U.S. National Forests and Grasslands: Part I evaluation of a water and carbon balance model. Forest Ecology and Management 353:260-268.

789 10.1016/j.foreco.2015.03.054

790

Sunday JM, Bates AE, and Dulvy NK. 2012. Thermal tolerance and the global redistribution of animals. Nature Climate Change 2:686-690.

Svenning JC, and Sandel B. 2013. Disequilibrium vegetation dynamics under future climate change. American Journal of Botany 100:1266-1286. 10.3732/ajb.1200469

Swets JA. 1988. Measuring the accuracy of diagnostic systems. Science 240: 1285-1293. 
800 Terrier A, Girardin PM, Périé C, Legendre P, and Bergeron Y. 2013. Potential changes in forest

801 composition could reduce impacts of climate change on boreal wildfire. Ecological

802 Applications 23:21-35.

803 Thompson I, Mackey B, McNulty S, and Mosseler A. 2009. Forest resilience, biodiversity, and

804 climate change. A synthesis of the biodiversity/resilience/stability relationship in forest

$805 \quad$ ecosystems. Montreal. p 67.

806 Thuiller W, Albert C, Araújo MB, Berry PM, Cabeza M, Guisan A, Hickler T, Midgley GF,

807 Paterson J, Schurr FM, Sykes MT, and Zimmermann NE. 2008. Predicting global change

808 impacts on plant species' distributions: Future challenges. Perspectives in Plant Ecology,

$809 \quad$ Evolution and Systematics 9:137-152. 10.1016/j.ppees.2007.09.004

810 Thuiller W, Lafourcade B, Engler R, and Araújo MB. 2009. BIOMOD - a platform for ensemble

811 forecasting of species distributions. Ecography 32:369-373. 10.1111/j.1600-

$812 \quad$ 0587.2008.05742.x

813 Virkkala R, Marmion M, Heikkinen RK, Thuiller W, and Luoto M. 2010. Predicting range shifts

814 of northern bird species: Influence of modelling technique and topography. Acta Oecologica

$815 \quad 36: 269-281.10 .1016 /$ j.actao.2010.01.006

816 Wang T, Wang G, Innes J, Nitschke C, and Kang H. 2016. Climatic niche models and their

817 consensus projections for future climates for four major forest tree species in the Asia-Pacific

818 region. Forest Ecology and Management 360:357-366. 10.1016/j.foreco.2015.08.004

819 Woodall CW, Oswalt CM, Westfall JA, Perry CH, Nelson MD, and Finley AO. 2009. An

820 indicator of tree migration in forests of the eastern United States. Forest Ecology and

$821 \quad$ Management 257:1434-1444. 10.1016/j.foreco.2008.12.013 
822 Woodward FI, and Williams BG. 1987. Climate and plant distribution at global and local scales. $823 \quad$ Vegetatio 69:189-197.

824 Worrall JJ, Rehfeldt GE, Hamann A, Hogg EH, Marchetti SB, Michaelian M, and Gray LK. 825 2013. Recent declines of Populus tremuloides in North America linked to climate. Forest $826 \quad$ Ecology and Management 299:35-51. 10.1016/j.foreco.2012.12.033

827 Wu X, Liu H, Guo D, Anenkhonov OA, Badmaeva NK, and Sandanov DV. 2012. Growth 828 decline linked to warming-induced water limitation in hemi-boreal forests. PLoS One $829 \quad 7: e 42619.10 .1371 /$ journal.pone.0042619

830 Xiao-Ying W, Chun-Yu Z, and Qing-Yu J. 2013. Impacts of climate change on forest 831 ecosystems in Northeast China. Advances in Climate Change Research 4:230-241. $832 \quad 10.3724 /$ sp.j. 1248.2013 .230

833 Yousefpour R, Jacobsen J, Meilby H, and Thorsen B. 2014. Knowledge update in adaptive 834 management of forest resources under climate change: a Bayesian simulation approach. 835 Annals of Forest Science 71:301-312.

836 doi:10.1007/s13595-013-0320-x

837 Zolkos SG, Jantz P, Cormier T, Iverson LR, McKenney DW, and Goetz SJ. 2014. Projected tree 838 species redistribution under climate change: implications for ecosystem vulnerability across 839 protected areas in the Eastern United States. Ecosystems 18:202-220. 10.1007/s10021-014$840 \quad 9822-0$ 
Figure 1

Modelling area and spatial distribution of bioclimatic domains in Quebec (Canada).

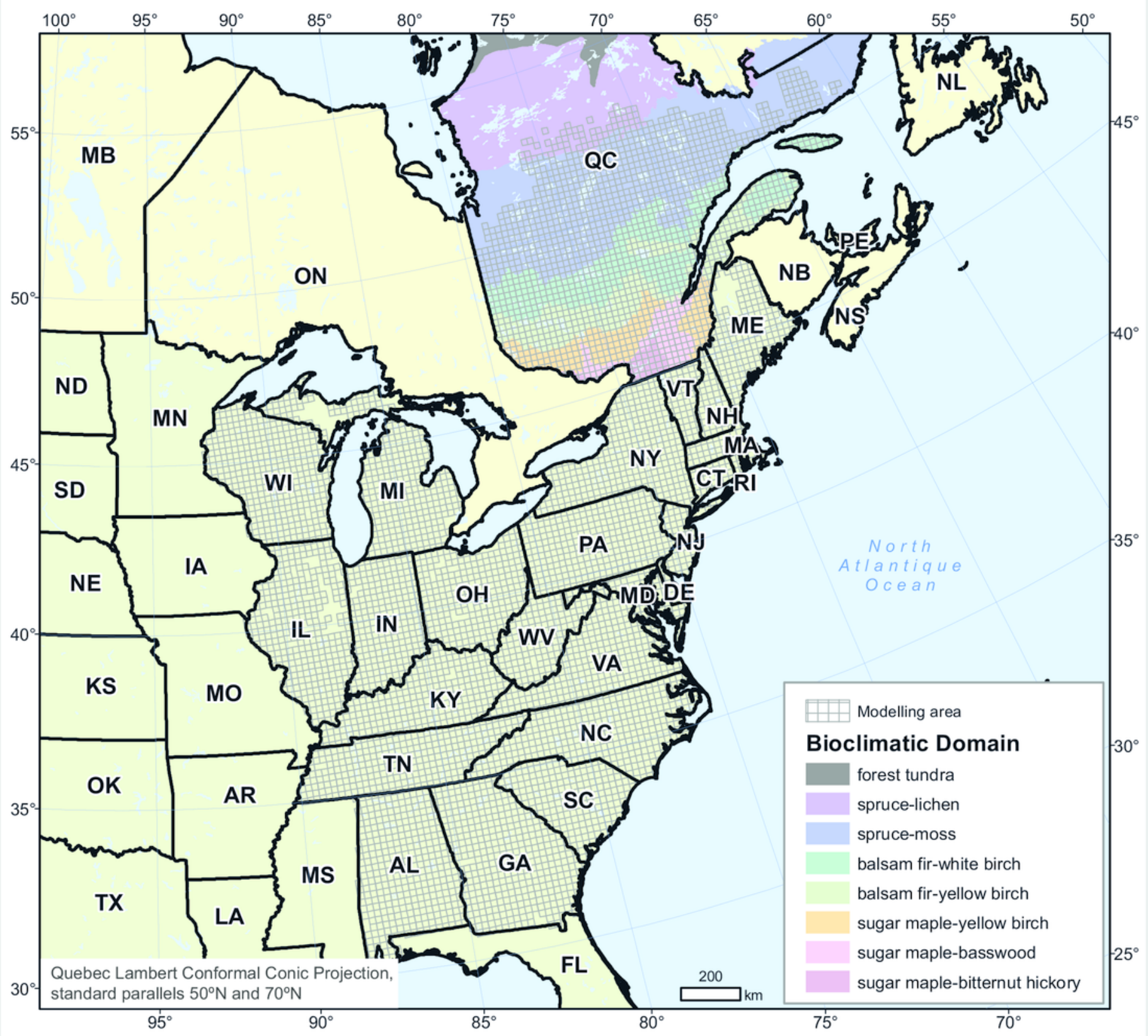




\section{Figure 2}

Forecasted changes (2080) in A) black spruce habitat, B) balsam fir habitat, C) white birch habitat, D) yellow birch habitat and E) sugar maple habitat.

UH: unsuitable habitat; LSH: persistent but less suitable habitat; PH: persistent habitat. Confidence values were calculated as the percentage of the 560 single predictions for a given cell that agreed with the average prediction for that cell. Values $\leq 50 \%$ : poor; $50 \%<$ values $\leq 75 \%$ : medium; values > 75\%: high. 
A)

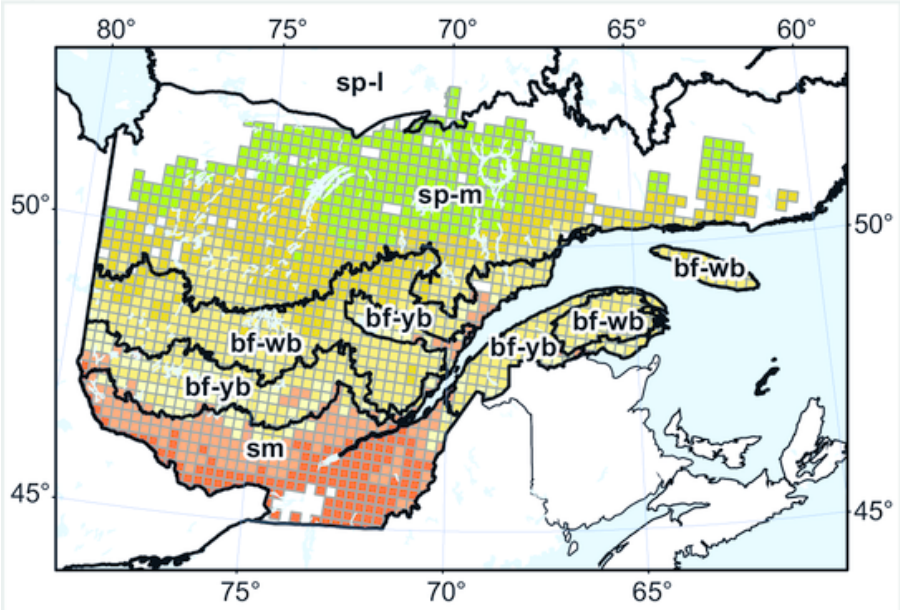

C)

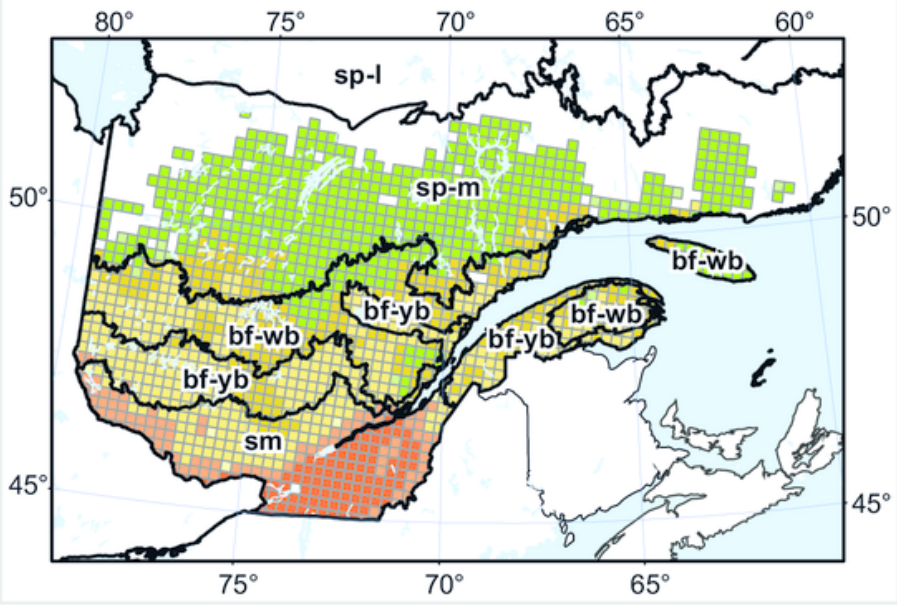

E)

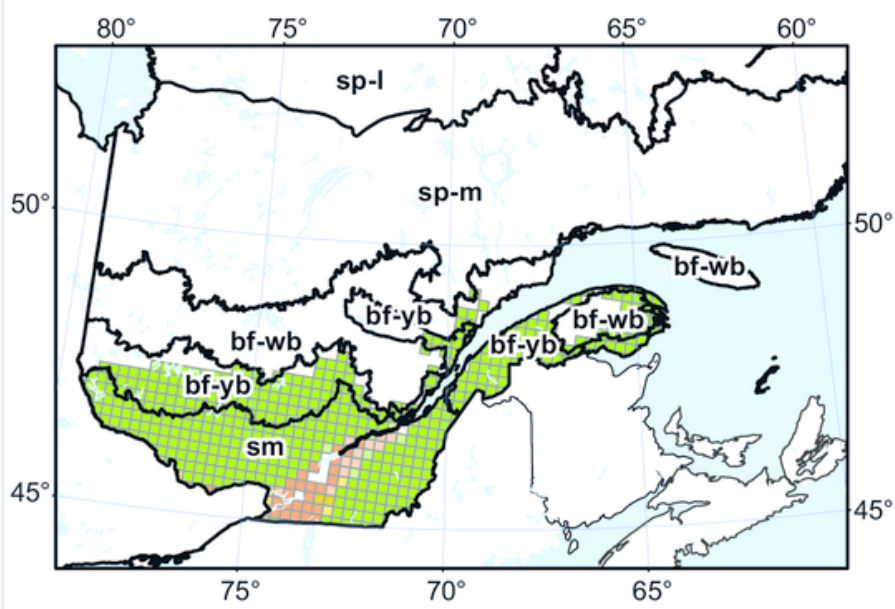

B)

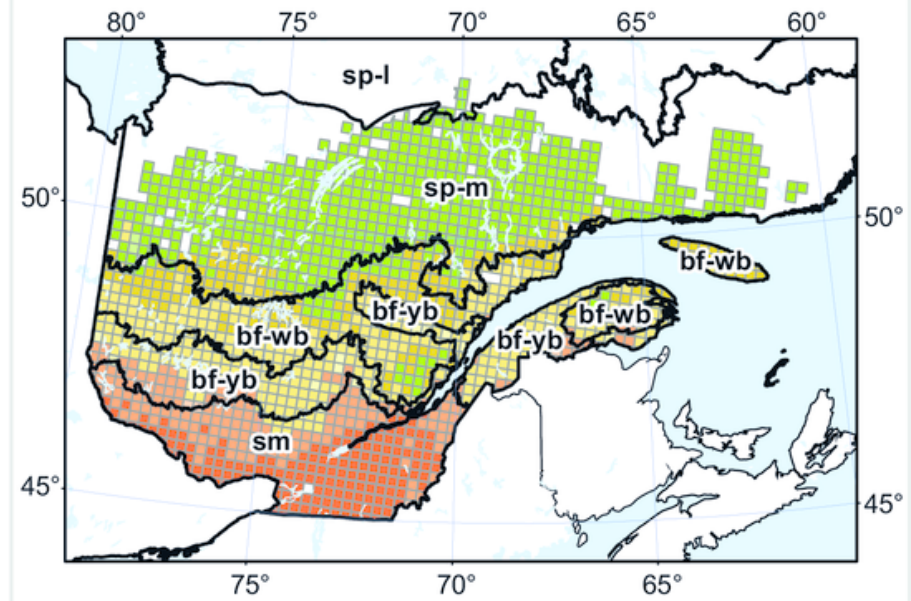

D)

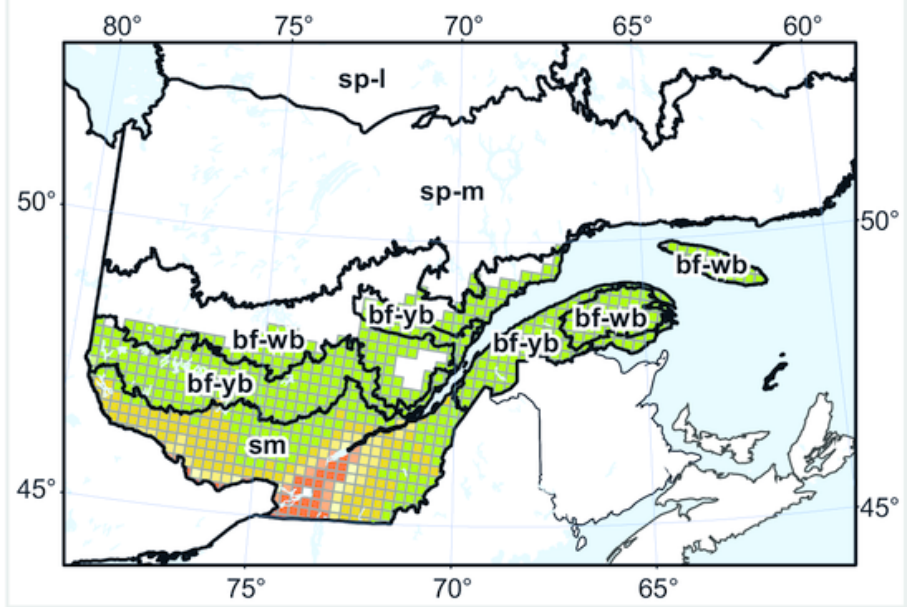

100 Quebec Lambert Conformal Conic Projection, standard parallels $46^{\circ} \mathrm{N}$ and $60^{\circ} \mathrm{N}$

Bioclimatic Domain spuce-lichen (sp-I)

spuce-moss (sp-m)

balsam fir-white birch (bf-wb)

balsam fir-yellow birch (bf-yb) sugar maple (sm)

Forecasted changes

$\mathrm{PH}$ (medium)

$\mathrm{PH}$ (high)

LSH (poor)

LSH (medium)

LSH (high)

UH (poor)

UH (medium)

UH (high) 
Figure 3

Number of tree species, among the 5 studied species, at risk of some climate-related stress in 2080.

We considered only cells in the study area where the baseline habitat was suitable for all 5 species.

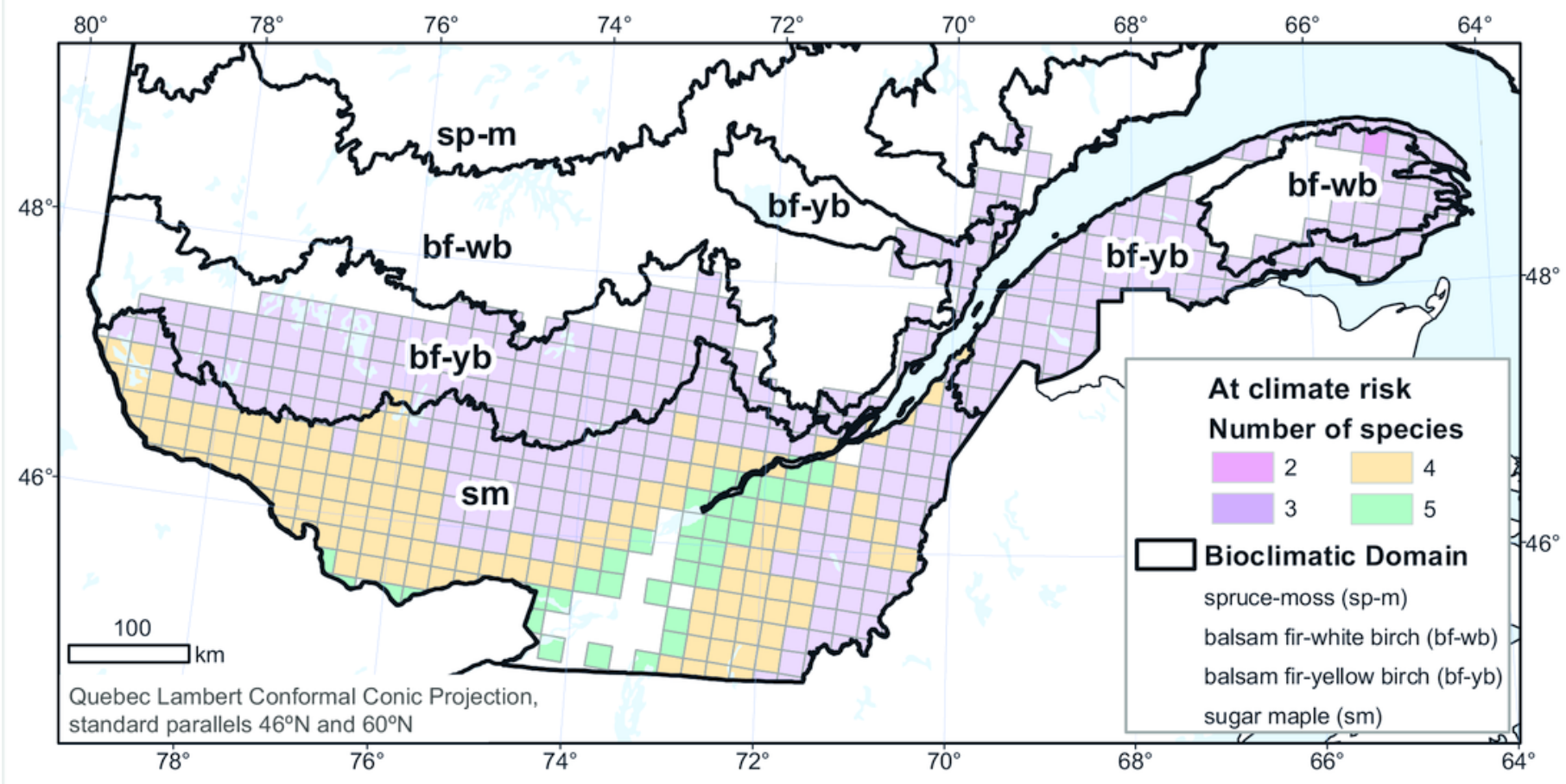




\section{Table $\mathbf{1}$ (on next page)}

Predictor variables used in tree habitat suitability models. 


\begin{tabular}{|c|c|c|c|}
\hline \multirow{2}{*}{ Climatic } & \multirow{2}{*}{ Topographic } & \multicolumn{2}{|c|}{ Edaphic } \\
\hline & & Surface deposit & Drainage \\
\hline \multirow{4}{*}{$\begin{array}{l}\text { Annual mean temperature }\left({ }^{\circ} \mathrm{C}\right) \\
\text { Annual total precipitation }(\mathrm{mm}) \\
\text { Ratio of summer precipitation over } \\
\text { annual total precipitation }\end{array}$} & Average elevation (m) & Eolian & Humid water regime \\
\hline & & Fluvio-glacial & Mesic water regime \\
\hline & & Glacial & Xeric water regime \\
\hline & & $\begin{array}{l}\text { Littoral, marine or lacustre } \\
\text { Organic } \\
\text { Rocky substrate } \\
\text { Slope or altered }\end{array}$ & \\
\hline
\end{tabular}




\section{Table 2 (on next page)}

Impact of climate change on tree habitat suitability in 2080 .

Forecasted changes in species habitat are illustrated both as absolute areas $\left(\mathrm{km}^{2}\right)$ and proportion of the baseline range for the region (\% of baseline). The baseline (1961-1990) range of a species is the total area $\left(\mathrm{km}^{2}\right)$ of all cells where the baseline average model predicted a suitable habitat for that species, within each bioclimatic domain or for all of the Quebec productive forest. The average agreement (\% ag.) was calculated as the mean percentage, within a given region, of single predictions for a given cell that agreed with the average prediction for that cell. 


\begin{tabular}{|c|c|c|c|c|c|c|c|c|c|c|}
\hline \multirow{3}{*}{ Species / Region } & \multirow{3}{*}{$\begin{array}{c}\text { Baseline } \\
\text { range } \\
\left(\mathrm{km}^{2}\right)\end{array}$} & \multicolumn{9}{|c|}{ Forecasted changes in species habitat } \\
\hline & & \multicolumn{3}{|c|}{ Unsuitable habitat } & \multicolumn{3}{|c|}{ Less suitable habitat } & \multicolumn{3}{|c|}{ Persistent habitat } \\
\hline & & $\mathrm{km}^{2}$ & $\begin{array}{c}\% \text { of } \\
\text { baseline }\end{array}$ & $\%$ ag. & $\mathrm{km}^{2}$ & $\begin{array}{c}\% \text { of } \\
\text { baseline }\end{array}$ & $\%$ ag. & $\mathrm{km}^{2}$ & $\begin{array}{c}\% \text { of } \\
\text { baseline }\end{array}$ & $\%$ ag. \\
\hline \multicolumn{11}{|l|}{ Black Spruce } \\
\hline Sugar maple domain & 103570 & 92348 & 89 & 77 & 11222 & 11 & 48 & & & \\
\hline Balsam fir-yellow birch domain & 97152 & 12347 & 13 & 66 & 84804 & 87 & 55 & & & \\
\hline Balsam fir-white birch domain & 136977 & 2778 & 2 & 65 & 134199 & 98 & 65 & & & \\
\hline Spruce-moss domain & 268668 & 209 & $<0.1$ & 66 & 139505 & 52 & 76 & 128953 & 48 & 94 \\
\hline Spruce-lichen domain & 2660 & & & & & & & 2660 & 100 & 99 \\
\hline Total (Quebec productive forest) & 609027 & 107682 & 18 & 74 & 369730 & 61 & 65 & 131614 & 21 & 94 \\
\hline \multicolumn{11}{|l|}{ Balsam Fir } \\
\hline Sugar maple domain & 109063 & 103583 & 95 & 76 & 5481 & 5 & 57 & & & \\
\hline Balsam fir-yellow birch domain & 97152 & 21249 & 22 & 59 & 75897 & 78 & 63 & 6 & $<0.01$ & 84 \\
\hline Balsam fir-white birch domain & 136977 & 1262 & 1 & 58 & 118967 & 87 & 70 & 16748 & 12 & 89 \\
\hline Spruce-moss domain & 253288 & & & & 29929 & 12 & 77 & 223359 & 88 & 90 \\
\hline Spruce-lichen domain & 2563 & & & & & & & 2563 & 100 & 99 \\
\hline Total (Quebec productive forest) & 599042 & 126093 & 21 & 71 & 230273 & 38 & 68 & 242675 & 41 & 90 \\
\hline \multicolumn{11}{|l|}{ White Birch } \\
\hline Sugar maple domain & 109077 & 69167 & 63 & 75 & 39910 & 37 & 63 & & & \\
\hline Balsam fir-yellow birch domain & 97152 & 1846 & 2 & 61 & 94926 & 98 & 69 & 379 & & 86 \\
\hline Balsam fir-white birch domain & 136977 & 5 & $<0.01$ & 59 & 108101 & 79 & 72 & 28871 & & 86 \\
\hline Spruce-moss domain & 235395 & & & & 34631 & 15 & 79 & 200764 & 85 & 85 \\
\hline Spruce-lichen domain & & & & & & & & & & \\
\hline Total (Quebec productive forest) & 578600 & 71019 & 12 & 74 & 277568 & 48 & 70 & 230014 & 40 & 85 \\
\hline \multicolumn{11}{|l|}{ Yellow Birch } \\
\hline Sugar maple domain & 109077 & 13915 & 13 & 79 & 52434 & 48 & 77 & 42728 & 39 & 95 \\
\hline Balsam fir-yellow birch domain & 95316 & & & & 372 & $<$ & 87 & 94944 & $99<$ & 93 \\
\hline Balsam fir-white birch domain & 66705 & & & & & & & 66705 & 100 & 94 \\
\hline Spruce-moss domain & 1469 & & & & & & & 1469 & 100 & 100 \\
\hline Spruce-lichen domain & & & & & & & & & & \\
\hline Total (Quebec productive forest) & 272567 & 13915 & 5 & 79 & 52806 & 19 & 78 & 205847 & 76 & 94 \\
\hline \multicolumn{11}{|l|}{ Sugar Maple } \\
\hline Sugar maple domain & 106902 & 14375 & 13 & 57 & 2536 & 2 & 71 & 89990 & 84 & 89 \\
\hline Balsam fir-yellow birch domain & 69917 & & & & & & & 69917 & 100 & 94 \\
\hline Balsam fir-white birch domain & 11683 & & & & & & & 11683 & 100 & 95 \\
\hline
\end{tabular}




\begin{tabular}{|c|c|c|c|c|c|c|c|c|c|c|}
\hline \multirow{3}{*}{ Species / Region } & \multirow{3}{*}{$\begin{array}{c}\text { Baseline } \\
\text { range } \\
\left(\mathrm{km}^{2}\right)\end{array}$} & \multicolumn{9}{|c|}{ Forecasted changes in species habitat } \\
\hline & & \multicolumn{3}{|c|}{ Unsuitable habitat } & \multicolumn{3}{|c|}{ Less suitable habitat } & \multicolumn{3}{|c|}{ Persistent habitat } \\
\hline & & $\mathrm{km}^{2}$ & $\begin{array}{c}\% \text { of } \\
\text { baseline }\end{array}$ & $\%$ ag. & $\mathrm{km}^{2}$ & $\begin{array}{c}\% \text { of } \\
\text { baseline }\end{array}$ & $\%$ ag. & $\mathrm{km}^{2}$ & $\begin{array}{c}\% \text { of } \\
\text { baseline }\end{array}$ & $\%$ ag. \\
\hline $\begin{array}{l}\text { Spruce-moss domain } \\
\text { Spruce-lichen domain }\end{array}$ & 209 & & & & & & & 209 & 100 & 99 \\
\hline Total (Quebec productive forest) & 188712 & 14375 & & 57 & 2536 & & 71 & 171800 & & 92 \\
\hline
\end{tabular}
1 